\title{
Rabelais and the Abbey of Saint-Victor Revisited
}

\author{
Brett Bodemer
}

\begin{abstract}
The seventh chapter of François Rabelais's Pantagruel concludes with a list of books attributed to the Abbey of Saint-Victor. The chapter's brief narrative foregrounds the catalog by touching on aspects of intellectual life in Paris, mentioning both the "great University of Paris" and the "seven liberal arts." It is not surprising, then, that critics have viewed the catalog as a broad critique of scholasticism. Evidence presented here warrants the addition of a further layer of nuance to this critique that is directly related to this abbey's contributions to education, reading, textual organization, and library classification.
\end{abstract}

I saw the Library of St. Victor: This most Antient [sic] Convent is the best seated of any in Paris; has very large Gardens, with shady Walks, well kept. The Library is a fair and large Gallery: It is open three days a week, and has a range of double Desks quite through the middle of it, with Seats and Conveniences of Writing for 40 or 50 People. . . In a part of it, at the upper end, are kept the Manuscripts; they are said to be 3000, which though not very ancient, have yet been found very useful for the most correct Editions of many Authors. This is one of the pleasantest Rooms that can be seen, for the Beauty of its Prospect, and the Quiet and Freedom from Noise in the middle of so great a City.

-Martin Lister, A Journey to Paris in the Year 1698

The Englishman Martin Lister published this description of the library of the Abbey of Saint-Victor after his visit to Paris in 1698. While savoring this bibliographic idyll, he would have been hard-pressed to foresee the abbey's suppression and demolition during the French Revolution or that its former site would come to be occupied in the twentieth and twenty-first centuries by the Faculty of Sciences of the University of Paris. ${ }^{1}$ The serendipity of this latter tenancy, however, might be construed as the resilient localization for nearly a thousand years of serious intellectual pursuit in Paris, for the abbey had been founded in 1114 by William of Champeaux, famous dialectician, master of the Paris schools, 
and teacher turned opponent of Peter Abelard. ${ }^{2}$ Interestingly enough, though the site has clear historical connections to the academic life of Paris, the vanished abbey and its erstwhile library are now most famous for an appearance in a single chapter of fiction: the seventh chapter of François Rabelais's first novel, Pantagruel. This celebrated chapter, first published in 1532, concludes with a list of books allegedly seen in the abbey library. Generally regarded as a satirical tour de force, this chaotic and often ribald list has informally entered the critical lexicon as the "Library of Saint-Victor."3

A list that grew longer in subsequent editions, the catalog includes such wonderful titles as La savatte de humilité ("The Gym Shoe of Humility") and Pantoufla decretorum ("The Codpiece of the Law"). ${ }^{4}$ Rabelais warns that these titles might be taken as mere "derision and jest," and a cursory glance seems to confirm this. ${ }^{5}$ One finds deformations of common Latin titles, such as Ars pettandi ("The Art of Farting") for Ars praedicandi ("The Art of Preaching"), and deformations of actual authors, for example, Tateret rendered as Tartaretus ("Craparetus"). ${ }^{6}$ We also find French titles such as Le moustardier de pénitence ("The Mustard Pot of Penitence") and Le créziou de contemplation ("The Crucible of Contemplation") that mimic the titling idioms of "old drivellers" whose works were reprinted and still "read in the 1520s and 1530s." Rabelais's title L'aguillion du vin ("The Goad to Wine") is an abbreviation of the real title, L'esguillon de l'amour divin ("The Goad to Divine Love"). ${ }^{8}$ And "Marmotretus, de babouynis et cingis, cum commento dorbellis" deforms the name of an actual author, Mamotretus, and a commentator, d'Orbellis (by Orbellis), to Dorbellis, giving, roughly, "Marmoset, of baboons and apes, with beautifully sleepy commentary." Rabelais biographer and specialist M. A. Screech assures us that "a large part of the laughter is provoked by the poor quality of the very doggy Latin." ${ }^{10}$ Yet the list is not all jokes, for in the prologue to his second novel, Gargantua, Rabelais urges his readers to look for a more serious meaning inside the titles. ${ }^{11}$

In looking for the deeper meaning in this list, many critics have attempted to identify the historical targets of the satire. One strategy has been to focus on individual titles, searching for bibliographic or biographical correlates and establishing a partial concordance between fictional and actual titles. ${ }^{12}$ These findings are then collated with other informed observations to show how the catalog collectively offers a critique of targets broader in scope than the abbey and its library, such as scholasticism, the anti-humanist reaction of the early sixteenth century, and remonstrations against Martin Luther. ${ }^{13}$ 
By contrast, in seeking to explain why Rabelais chose to target this particular abbey, some critics have looked to discrete historical incidents of Rabelais's era. A. H. Schutz notes that Augustinian officials regulating the abbey had rejected reforms favored by Erasmus earlier in the century, while Screech points out that Pantagruel was published the same year that the canons regular of the Abbey of Saint-Victor lobbied to print a book criticizing Erasmus. ${ }^{14}$ These contemporary particulars are both feasible and fascinating but rather minute in scope.

When accounting for Rabelais's choice of the abbey's library as a target, however, the tendency to generalize resurfaces. More often than not, the abbey library is cursorily characterized as a generic scholastic library. One modern translator goes a bit further, remarking that it was "noted for its richness in theological works."

While all these characterizations have clear merit, there is warrant for going much further when considering why Rabelais linked his satire to this particular abbey and to its library. Hugh of Saint-Victor and other important figures associated with the abbey played foundational roles in the transformation of reading and the organization of knowledge that have come to be known as scholasticism. Rabelais's contemporary readers, all of them educated, were also likely to have known that the Abbey of Saint-Victor was an important presence at the onset of this vast change. In addition, Hugh of Saint-Victor made noted contributions to library classification, and the entire complex of scholastic structures came to be physically embodied in the abbey's own library: in its classification systems, its rules of etiquette, the physical design of many of the texts, and, of course, its catalogs. While none of these features is unique to this library, the abbey's contributing role to their growth may be taken into account. Moreover, Rabelais's use of a catalog as a vehicle for lampooning this abbey's library is especially appropriate, for his critique operates not only by attribution to the abbey and a wild mockery of titles and titling idioms but also by the incongruity between his chaotic litany and the notions of order that lie at the heart of scholasticism and of cataloging itself. Supporting evidence for these assertions can be found by exploring the history of the Abbey of Saint-Victor, evaluating the abbey's intellectual contribution to scholasticism, and considering the organization of its bibliographic collection as revealed by library historians and two catalogs compiled for the abbey in 1514.

\section{The Abbey of Saint-Victor and Its Library}

The Abbey of Saint-Victor antedated even the University of Paris, a consortium it joined as a founding member in the thirteenth century. ${ }^{16}$ 
The abbey's founder was not, indeed, Saint Victor (a fourth-century martyr of Moorish descent) but William of Champeaux, and it was regularized as an order of Augustinian canons in 1114. ${ }^{17}$ What distinguished this abbey from other Augustinian establishments was its emphasis on education. The eighteenth-century historian Claude Fleury emphasized that "the canons diligently observed divine offices night and day; they performed manual labor, kept a great silence, and never left off studying and teaching." 18

The intellectual heritage of the abbey rapidly spread far beyond its walls. The man who gained renown as Hugh of Saint-Victor arrived at the abbey a year or two after its founding. ${ }^{19}$ Some consider his De sacramentis christianae fidei (On the sacraments of the Christian faith) to be the first scholastic summa or even the "grandmother of all the Summae." ${ }^{0}$ If we take the liberty of tracing the influential genre of the summa to its intellectual ancestors, then the honor of "grandfather" might be assigned to Abelard. At one more remove, William of Champeaux, as founder of the Abbey of Saint-Victor and as Abelard's former master, might be designated as "great-grandfather" of the summae on both sides.

In the 1120s Hugh wrote the Didascalicon, a small but very influential book, the popularity of which is confirmed by the fact that it survives in more than a hundred manuscript copies dating from the twelfth through fifteenth centuries. ${ }^{21}$ Intended as a guide for students new to the Abbey of Saint-Victor, the Didascalicon offered a comprehensive, revised outline of education..$^{22}$ In his reassessment of knowledge, Hugh posited philosophy as a single whole, encompassing all other arts, including the previously lowly esteemed mechanica. Reviving the ancient notion of the seven liberal arts, Hugh placed them in a larger context. ${ }^{23}$ Since, in his arrangement, all knowledge can be conceived of as an ensemble, everything admits of being classified in a corresponding hierarchical schema. ${ }^{24}$ According to his divisions, for instance, one might put "butter" under the following classes: Philosophy $>$ Mechanical Sciences (i.e., Adulterate) $>$ Hunting $>$ Food Preparation $>$ Side Dishes $>$ Porridges $>$ Butter. ${ }^{25}$ Yet in the Didascalicon Hugh also explained how such serious classification could still be versatile:

Let no one be disturbed that among the means employed by medicine I count food and drink, which earlier I attributed to hunting. For these belong to both under different aspects. For instance, wine in the grape is the business of agriculture; in the barrel, of the cellarer, and in its consumption, of the doctor. Similarly, the preparing of food belongs to the mill, the slaughterhouse, and the kitchen, but the strength given by its consumption, to medicine. ${ }^{26}$ 
For these reasons, Hugh is credited with establishing key groundwork for medieval and even modern library classification. ${ }^{27}$ With his conceptions of knowledge, his vision of reading, and his expansion of the seven liberal arts, Hugh of Saint-Victor influenced several generations, which in turn increased the production of books, created many new libraries, and transformed the practice of reading. ${ }^{28}$

Another compelling figure associated with the Abbey of Saint-Victor is Peter Lombard, who eventually became bishop of Paris. The earliest document relating to Lombard is a letter recommending him to the first abbot of Saint-Victor. He may have received schooling at the abbey, and it is also possible that he bequeathed his personal books to the abbey library. ${ }^{29}$ Nikolaus Häring, a specialist in medieval theological texts, characterizes Peter Lombard's commentaries as rooted in the thought and lectures of Hugh of Saint-Victor and further notes that the Victorine tradition of commentary was "carried on by three masters of great renown: Peter Comestor, the famous magister historiarum, Peter the Chantor, the leading moralist and exegete of his time, and master Stephen Langton, the future cardinal." ${ }^{30}$

Lombard was widely known for his gloses, or commentaries, on the Psalter and the Bible, and though the glose was by no means new, twelfthcentury scholars produced them with greater intricacy than ever before and Lombard's were among the most "highly developed." ${ }^{31}$ Lombard is most famous for his Libri sententarium, a compilation of earlier auctoritates that reigned as a standard theology textbook until the middle of the sixteenth century. ${ }^{32}$ Ulrich Langer maintains that late scholastic thought survives primarily through commentaries on this work. ${ }^{33}$

The Libri sententarium adapted many features of the glose: rubrics, subheadings, and red source notes in the margins. Such complex, onthe-page appliances were both symptoms and instruments of a shift in the practice of reading, for whereas the monastic lectio involved "steady reading to oneself, interspersed by prayer," the newer, scholastic lectio "involved a more ratiocinative scrutiny of the text and consultation for reference purposes." ${ }^{34}$ Accordingly, texts found themselves divided into books, chapters, and paragraphs and were equipped with running titles, analytical tables of contents, indexes, and footnotes, all of which made them easier to search. ${ }^{35}$ This not only accommodated the newer style of reading but physically embodied its motivating principles.

The Abbey of Saint-Victor, then, from its ancient founding by William of Champeaux and through subsequent intellectual contributions from Hugh, Peter Lombard, and others, can be seen as root and trellis of a perceived structure of knowledge. This conception informed the shape 
of education, and its governing principles came to be inscribed in receptacles of various sizes, not only in the texts, but even in the layout of those texts in their largest physical array: the abbey library.

And how was that library arranged? In a practice similar to that of other religious houses, the books at Saint-Victor were not herded into one place but were stored functionally: liturgical manuscripts were kept in the choir, books for reading aloud at mealtime were kept near the refectory, and books on the art of dying did not leave the infirmary, even after those most in need of them had gone. ${ }^{36}$ The main collection, however, was housed in a common reading hall. Though it is not known when this hall first opened, the date can plausibly be assigned to the mid- or late thirteenth century, as a trend to similar arrangements can be found in references to Cluny in 1270 and the Sorbonne in $1289 .{ }^{37}$ In the common reading hall, the books were chained to long, inclined tables. Though it is tempting to think of these chains as restricting access to texts, the chains in fact facilitated access, for the chains kept books where they could be found and also guarded them from theft, a not-uncommon fate for such expensive and portable items. ${ }^{38}$ In fact, the advent of chained libraries in the thirteenth century was another physical embodiment of the shift in reading. ${ }^{39}$ Books, rather than being committed to a single reader, were now available to many potential readers, and a library was no longer a book depository but a reading room. ${ }^{40}$ Whereas in monastic lectio one might read a work over several months in full or midvoice, the newer consultation reading covered more material in less time and, if not altogether silent, was at least conducted at a lesser volume, as witnessed by the admonition at Saint-Victor's library to "communicate by signs as much as possible and read with a low voice." ${ }^{41}$ Similar rules for the library of the Sorbonne enjoined that "as much as possible, silence should reign in the library." ${ }^{42}$

One might reasonably ask what the common collection at the abbey contained. It was assembled on the perceived basis of frequent demand and formed the medieval equivalent of a modern standard reference section. ${ }^{43}$ It was open not only to resident canons but to students from the Sorbonne and the College of Navarre, rendering access not only to theological works but to works on jurisprudence and medicine. ${ }^{44}$ After renovations in the early sixteenth century, an expanded collection was transported and rechained in a larger building with many windows. ${ }^{45}$ When Rabelais wrote Pantagruel, the renovated premises were not only commodious but still relatively new-newer, for instance, than the renowned library at the College of Navarre, which had assumed new lodgings on the cusp of the century, and newer still than the library of 
the Sorbonne, which had undertaken a similar move in the $1480 \mathrm{~s} .{ }^{46}$ The building, in fact, was the same that Lister saw when he visited in 1698, although by then bibliographic materials had been moved to a higher floor due to severe flooding in $1651 .{ }^{47}$

When the common collection was ushered into its new premises in the early sixteenth century, Claude de Grandue, the abbey armarius, or librarian, compiled two catalogs. As Grandue operated much in the manner of his predecessors, his catalogs represent not only the contemporary contents of the collection but also the institutional traditions, methods, and philosophy applied to those contents. ${ }^{48}$ These extant catalogs of 1514 have been made widely available through the transcriptions of Gilbert Ouy, and an examination of these transcriptions allows us to see what Grandue was up to. ${ }^{49}$ One catalog lists the items alphabetically by author, the other in order of their physical disposition in the library. ${ }^{50}$ In addition to the authors' names and titles (when available), his catalog entries include identifying features such as size, material, first words of the second page, last words of the penultimate page, and total number of pages, proving that the catalogs served both administrative purposes (inventory) and the needs of users (retrieval). The catalogs, like other texts of the time, are also inundated with alphanumeric coding. Certain elements of information are signaled by a sequence of alphabetical markers, and additional alphanumeric markers designate the location of an item in the library, with the coding being duplicated on the item itself. Thus, the catalogs, designed to contain and control, reciprocally bear the same markers of containment and control as the texts they represent. ${ }^{51}$

While both catalogs represent the abbey's physical collection, the topographical catalog is particularly interesting because it is forced to mediate between the ideal of a rationally classifiable universe and the physical features of the contents of the collection. Several centuries had elapsed since the days of Hugh of Saint-Victor, and his comprehensive schema, though evident as a substrate, was clearly compromised by considerations of educational purpose, collection diversity, and the mundane realities of textual production. ${ }^{52}$ Classed under fifty-two headings, this catalog deploys three alphabets, A-T, AA-TT, and AAA-OOO. It still reflects traditional priorities by dedicating the first alphabet to sacred texts, with Old and New Testaments leading to biblical commentaries, followed by commentaries on Lombard's Libri sententarium and canon law. But the rather incongruous subjects of civil law and medicine round out this alphabet. Similarly, the double alphabet is inaugurated by church fathers and Victorine authors, but its final block, TT, 
indiscriminately houses French texts and translations, with no apparent regard for subject or author. The triple alphabet is weighted with histories, but its final ranges, $\mathrm{NNN}-\mathrm{OOO}$, comprise a veritable miscellany, Cicero rubbing shoulders with Thomas Aquinas and Petrarch elbowto-rib with Jacobus de Voragine. In an era of scribal compilation and expensive materials, these last blocks of the triple alphabet may have been a necessary concession to the reality that many texts were often bound together in one physical item. ${ }^{53}$

These details emphasize how principles of representation and containment, extrapolated from a particular conception of knowledge, inhered in the conception and creation of medieval libraries and were particularly germane to the Abbey of Saint-Victor's library, given its contribution to those conceptions. In the physical library of the abbey, readers were admonished to keep quiet. In texts, pages were subjected to a host of formal structures. These structures themselves were applications of a conceptual design that delimited and contained the universe; it was a design, moreover, that permitted texts to be ranged in classes. Alphanumeric coding, in concert with these classes, permitted items to be arrayed in a reading hall, which became a microcosm of the universe as so conceived. This was the ideal, of course, but as the topographical catalog of 1514 reveals, changes in educational needs and the diversity of physical items offered resistance. The topographical catalog, mediating between classificatory ideals and the multiform physical library, evidences a yielding of the ideal before such exigencies. A compromised collection of this sort-housed in an abbey that promulgated the amenability of all knowledge to order-impugns the potency of that impulse to order the universe.

This is one of the reasons that Rabelais's choice of a catalog as a vehicle for his satire is particularly appropriate. That is not to say that Rabelais was directly critiquing the catalogs of Saint-Victor and Grandue. Rather, he used the structure of the catalog qua catalog to critique the impulse to catalog itself. Contrasting his catalog with those compiled by Grandue, one can see not only how Rabelais deformed the practices of the day but, more important, how his total disregard of the catalog function of collocation indicted the impulse to classification.

Grandue's catalogs provided information for locating items, identifying items, and, via classification, collocation. Rabelais's critique does not seem to operate on the first two functions in any serious way. In the first edition of Pantagruel, he gave titles and a few authors but no information about either locations or copies. ${ }^{54}$ In later iterations, he expanded his repertoire to include catalog-speak about the number of volumes or 
particulars of an item's binding or condition but never took it upon himself to offer information about locations. ${ }^{55}$ Although this omission surely represents missed comic opportunities, the author's decision to avoid evoking the physical interior of the abbey library encourages the reader to instead remain engaged with the intellectual thrust of the critique.

By contrast, his neglect of collocation is situated in the latter domain. The critic Barbara Bowen, in one of her detailed studies of Rabelais and referring to a later edition of Pantagruel, writes: "The modern reader's immediate reaction to a list of 139 items is that there must be a structural principle at work somewhere, but I do not see any attempt at structuring this catalog. ${ }^{56}$ She notes that there are "ninety titles in French and fortynine in Latin" and that "at least thirty items joke with defecation ... or syphilis . . and . . twenty-three have to do with food." ${ }^{57}$ Bowen fails to remark that these are all hopelessly interspersed. The 1532 catalog is quite the same in all these respects, only shorter.

In fact, the most notable structural feature of Rabelais's "catalog" is precisely its lack of order. Certainly, Rabelais knew how to order a list, for the list of games in his Gargantua is bundled and enumerated by type.$^{58}$ Nor did he object to bibliographic order on principle, for in chapter 53 of Gargantua one finds the ideal Abbey of Thélème graced with collections divided by language and separated by floors. ${ }^{59}$ Bowen, as we have seen, states that the modern reader is inclined to look for underlying structure in the catalog of Saint-Victor drawn up by Rabelais. ${ }^{60}$ However, there is no reason to deny this inclination to Rabelais's contemporary readers, who were, chronologically if not temperamentally, so much closer to an intellectual training that made a virtue of system.

The haphazardness of the catalog in chapter 7 of Gargantua also stands in stark contrast to the meticulous procedure pursued in the following chapter in a related discussion of education. In that chapter, while the giant Gargantua prescribes his educational desiderata for his son, he takes his model-the prevailing educational system founded on the seven liberal arts-and systematically alters its parameters. As Edwin M. Duval, one of the premier modern authorities on Rabelais, notes: "Once we have recognized the structure behind the details of Gargantua's program we cannot help but be struck by the crucial ways in which the details themselves modify and transform the structure that subtends them. Rabelais seems in fact to use the implicit structure of the curriculum as a norm against which to measure the most important innovations contained in the program proposed by Gargantua." ${ }^{61}$ Though Rabelais proceeds in chapter 8 by means of point and counterpoint, in chapter 7 he takes the opposite tack and indicts the norm by wholly ignoring it. He scorns the paradigm of the medieval library 
catalog by denying any coherence to a form whose whole point is structural coherence. The disorder of his list, resolutely resisting attempts at classification ex post facto by the reader, challenges the very notion, so strong in the writings of Hugh of Saint-Victor, that the universe admits of classification. This list is more than a comic assemblage of parts. It is truly a "scrambled encyclopedia," and when Rabelais deliberately associates it with the Abbey of Saint-Victor, he challenges the legitimacy of structures produced by, and seemingly supporting, the institution's long-standing claims to intellectual authority. ${ }^{62}$ Rabelais's mess of a cata$\log$, through formal subversion, let his contemporary readers know that the emperor had no clothes and that the seemingly redoubtable walls of the abbey, in spite of appearances, were set on shifting sand.

\section{Conclusion}

The lion's share of Pantagruel's seventh chapter consists of a concluding catalog attributed to the Abbey of Saint-Victor. The chapter's brief preceding narrative foregrounds the catalog by touching on various aspects of intellectual life in Paris, mentioning both the "great University of Paris" and the curricula of "all the seven liberal arts." ${ }^{63}$ It is not surprising, then, that critics have viewed the catalog as a broad critique of scholasticism. The evidence presented in this article warrants the addition of a further layer of nuance to this critique, directly related to the abbey's contributions to scholastic reading, textual organization, and projects for the universal organization of knowledge. It may be objected that Rabelais mentions the abbey only once, and seemingly in passing, as the narrator introduces the catalog, and yet, as literary critic Raymond La Charité points out, a reference in Rabelais can open "floodgates." ${ }^{4}$

Consideration of the critique at this level of specificity in no way diminishes other interpretations but serves to further enrich our understanding of the author's response to varieties of reading and intellectual activity. What is more, in savoring the parameters of his wild, "scrambled" catalog, we can also delight in his use of a literary form as a means of critiquing the purposes embodied in that form itself.

\section{Notes}

1. Gilbert Ouy, "Saint-Victor de Paris," in Histoire des bibliothèques françaises ([Paris]: Promodis-Éditions du Cercle de la Librairie, 1989), 1:86.

2. Abelard is perhaps most widely known for a certain incapacity resulting from his relations with his student Héloïse, but he was also an influential and controversial figure who greatly influenced philosophy and the methods of discourse in universities. See William Clark, Academic Charisma and the Origins of 
the Research University (Chicago: University of Chicago Press, 2006), 75-76. For a deeper account, see D. E. Luscombe, The School of Peter Abelard: The Influence of Abelard's Thought in the Early Scholastic Period (Cambridge: At the University Press, 1969).

3. Although the critics have Rabelais's fictional list in mind and use the words "catalog" and "list" in such discussions either for the sake of ease or through an inadvertent vagary of focus, they usually refer to the list in noun form as the library of Saint-Victor, as though there had been no actual library at the Abbey of Saint-Victor. This is a great diachronic victory for Rabelais, because his satiric catalog has metonymically trumped its target. (To gauge the prevalence of this noun construction, I performed a JSTOR keyword search of "library of Saint-Victor," which yielded thirty-four results, while a search of "cata$\log$ of Saint-Victor" yielded none. Search performed June 28, 2011.)

4. Jacques Boulenger, Rabelais: Euvres complètes ([Paris]: Gallimard, 1955). All original Rabelais text is drawn from this edition; the catalog spans pages 195-202. Except where otherwise indicated, English translations of Rabelais are from Donald Frame, The Complete Works of François Rabelais (Berkeley: University of California Press, 1991); the catalog of the Abbey of Saint-Victor spans pages 153-58.

5. Frame, Complete Works, 4.

6. The first title, Ars pettandi, is in Boulenger, Rabelais, 196; the second title, Ars praedicandi, is in Gilbert Ouy, Les manuscrits de l'Abbaye de Saint-Victor: Catalogue établi sur la base du répertoire de Claude de Grandue (1514) ([Paris]: Brepols, 1999), 1:331. For the authors, see Boulenger, Rabelais, 196n10.

7. "Old drivellers" is in V. L. Saulnier, Rabelais dans son enquête (Paris: Société d'Édition d'Enseignement Supérieur, 1983), 100; "read in the 1520s and 1530s" is in M. A. Screech, Rabelais (Ithaca, NY: Cornell University Press, 1979), 61.

8. Le Duchat et Le Motteux, Les grandes croniques de Gargantua (Niort: L. Favre, 1879), 2:176.

9. Translation mine.

10. Screech, Rabelais, 62.

11. The Gargantua prologue is found in Frame, Complete Works, 3-5. Critical discussions of this prologue have generated various opinions about what Rabelais is urging upon his readers. Duval concludes that one should look for the moral meaning ("Interpretation and the 'Doctrine absconce' of Rabelais' Prologue to Gargantua," in Études Rabelaisiennes [Geneva: Librairie Droz, 1985], 18:17). François Cornilliat suggests that the prologue was written to surmount perceived stylistic failings of Pantagruel ("On Words and Meaning in Rabelais Criticism,” in Études Rabelaisiennes [Geneva: Librairie Droz, 1998], 35:23). Jan Miernowski suggests that Rabelais is exhorting his readers to misread his work ("Literature and Metaphysics: Rabelais and the Poetics of Misunderstanding," in Études Rabelaisiennes [Geneva: Librairie Droz, 1998], 25:134). Given such a diversity of opinions, I lean to the opinion of Raymond C. La Charité, namely, that "we can take the narrator's advice at face value" ("Rabelais and the Silenic Text: The Prologue to Gargantua," in Rabelais's Incomparable Book, ed. Raymond C. La Charité [Lexington, KY: French Forum Publishers, 1986], 78). In my previous investigations of Pantagruel's seventh chapter, I have proposed a variety of deeper meanings, but most particularly the way that Rabelais's handling of titles poses a linguistic challenge to the stability of books and knowledge (Brett B. 
Bodemer, "Rabelais Unsheathes the Book: The Linguistic Critique Offered by the Catalog of Saint-Victor's," International Journal of the Book 7, no. 1 [2009]: 103-14; and Bodemer, "The Title as Suspect Codpiece" [MA thesis, University of Hawai'i at Mānoa, 2006]).

12. One nineteenth-century author, Paul Lacroix, tried to establish a link between each title in Rabelais and one in the 1514 catalogs of the Abbey of Saint-Victor, but some of the attempts are so belabored as to be laughable; see Paul Lacroix and Gustave Brunet, Catalogue de la bibliothèque de l'Abbaye de SaintVictor au seizième siècle (1862; Geneva: Slatkine Reprints, 1968).

13. For anti-humanist reaction, see Screech, Rabelais, 60-63; for Luther, see Lucien Febvre, The Problem of Unbelief in the Sixteenth Century, trans. Beatrice Gottlieb (Cambridge, MA: Harvard University Press, 1982), 316-30.

14. A. H. Schutz, "Why Did Rabelais Satirize the Library of Saint-Victor?," Modern Language Notes 70, no. 1 (1955): 40-41; Screech, Rabelais, 61.

15. Frame, Complete Works, 826.

16. Ouy, "Saint-Victor de Paris," 86.

17. L'Abbé É. Michaud, Guillaume de Champeaux et les Écoles de Paris au XIIe siècle (Paris: Librairie Académique, 1867), 412.

18. Claude Fleury, Histoire ecclésiastique, XV, 176, cited in ibid., 400, translation mine.

19. Steven Chase, Contemplation and Compassion: The Victorine Tradition (Maryknoll, NY: Orbis Books, 2003), 30; David Knowles, The Evolution of Medieval Thought (Baltimore, MD: Helicon Press, 1962), 143.

20. "First scholastic summa" in Chase, Contemplation, 31; "grandmother of all the summae" in Knowles, Evolution, 143.

21. Alain Besson, Medieval Classification E Cataloguing (Biggleswede, UK: Clover Publications, 1980), 17-18.

22. Jerome Taylor, The Didascalicon of Hugh of St. Victor (New York: Columbia University Press, 1961), 3.

23. Donatella Bebbiai-Dalla Guarda, "Classifications et classements," in Histoire des bibliothèques françaises, 1:374.

24. Ibid., 374.

25. Besson, Medieval Classification, 10-14.

26. Taylor, Didascalicon, 79.

27. Guarda, "Classifications et classements," 374; Besson, Medieval Classification, 8-17.

28. Guarda, "Classifications et classements," 374.

29. Knowles (Evolution, 171) presents Lombard's attendance at school as a fact; Nikolaus M. Häring makes the same claim in "Commentary and Hermeneutics," in Renaissance and Renewal in the Twelfth Century, ed. Robert L. Benson and Giles Constable (Cambridge, MA: Harvard University Press, 1982), 191. Marcia Colish, in her multivolume biography of Lombard, leaves his attendance as undecided (Peter Lombard [Leiden: E. J. Brill, 1994], 1:17-21). For the possible bequest of books, see Ouy, Les manuscrits, 39.

30. Häring, "Commentary and Hermeneutics," 194.

31. Malcolm Beckwith Parkes, "The Influence of the Concepts of Ordinatio and Compilatio on the Development of the Book," in Medieval Learning and Literature, ed. J. J. G. Alexander and M. Gibson (Oxford: Clarendon Press, 1976), 116. 
32. Philipp W. Rosemann, Understanding Scholastic Thought with Foucault (New York: St. Martin's Press, 1999), 84.

33. Ulrich Langer, Divine and Poetic Freedom in the Renaissance: Nominalist Theology and Literature in France and Italy (Princeton, NJ: Princeton University Press, 1990), 19.

34. Parkes, "Influence," 115.

35. Ibid., 135.

36. Ouy, Les manuscrits, 28-29.

37. Jean Vezin, "Le mobilier des bibliothèques," in Histoire des bibliothèques françaises, 1:368-69.

38. From the standpoint of protecting assets, such chaining of materials was necessary, as "a manuscript might well be worth more than a house, and was more easily concealed and stolen" (Kenneth M. Setton, "From Medieval to Modern Library," Proceedings of the American Philosophical Society 104, no. 4 [1959]: 371-90, 379).

39. Ibid., 368-69.

40. François Dolbeau, "Les usagers des bibliothèques," in Histoire des bibliothèques françaises, 2:398.

41. Dom Jean Becquet, "Les bibliothèques de chanoines réguliers (Prémontrés, Victorins, etc.)," in Histoire des bibliothèques françaises, 1:91.

42. Alfred Franklin, La Sorbonne: Ses origines, sa bibliothèque, les débuts de l'imprimerie à Paris et la succession de Richelieu d'après des documents inédits (Paris, 1865; Amsterdam: Gérard Th. Van Heusden, 1968), 100.

43. Ouy, Les manuscrits, 28.

44. Marie-Henriette Jullien de Pommerol, "Livres d'étudiants, bibliothèques de collèges et d'universités," in Histoire des bibliothèques françaises, 1:98.

45. Ouy, "Saint-Victor de Paris," 86.

46. Anne Prache, "Bâtiments et décor," in Histoire des bibliothèques françaises, $1: 360$.

47. Louis Desgraves, "La bibliothèque de l'Abbaye de Saint-Victor et son inspection en 1684," in Histoire des bibliothèques françaises, 2:294.

48. Ibid., 35.

49. Ouy, Les manuscrits. Ouy bases his transcribed catalog on the manuscript catalogs of Grandue.

50. Ibid., 55-56.

51. Analysis based on author's examination of ibid.

52. Ibid., 54-55.

53. Analysis based on author's examination of ibid.

54. The first edition of Pantagruel (1532) has only forty-three titles. See V. L. Saulnier, Pantagruel: Première publication critique sur le texte original (Geneva: Librairie Droz, 1965), 37-38.

55. Later editions of Pantagruel of 1537 have nearly 140 titles. Some include notes about the number of volumes or physical features, for example, "Soixante et neuf breviaries de haulte gresse," translated by Frame as "Sixty-Nine WellThumbed Vintage Breviaries," and "Moillegroin Doctoris cherubici, De Origine patepelutarum et torticollorum ritibus lib. septem," translated by Frame as "Babybib, the Cherubic Doctor, on the origin of the hairypaws and the rites of the wrynecks . . seven books" (Complete Works, 157). See also Boulenger, Rabelais. 
56. Barbara C. Bowen, Enter Rabelais, Laughing (Nashville, TN: Vanderbilt University Press, 1998), 96.

57. Ibid., 96-97.

58. Boulenger, Rabelais, 86.

59. Ibid., 173.

60. Bowen, Enter Rabelais.

61. Edwin M. Duval, "The Medieval Curriculum, the Scholastic University, and Gargantua's Program of Studies," in La Charité, Rabelais's Incomparable Book, 31 .

62. W. Scott Blanchard proposes the term "scrambled encyclopedia" to describe not only parts of Gargantua and Pantagruel but entire works, such as Robert Burton's Anatomy of Melancholy and Agrippa von Nettesheim's De Incertitudine et Vanitate Scientiarum et Artium. Blanchard writes that in the scrambled encyclopedia "the categorical confusion and realignment of traditional hierarchies of knowledge . . . become curricular analogues to the deformities and transformations of the literary grotesque" (Scholar's Bedlam: Menippean Satire in the Renaissance [London: Associated University Presses, 1995], 87). It is viable to consider the "scrambled" catalog of our chapter, with its categorical confusion, as another such distortion and curricular analogue.

63. Frame, Complete Works, 152-53.

64. Raymond C. La Charité, "Rabelais and the Silenic Text: The Prologue to Gargantua," in La Charité, Rabelais's Incomparable Book, 75. 